\title{
SLAKED LIME, BAKING SODA AND MINERAL OIL FOR BLACK SPOT AND POWDERY MILDEW CONTROL IN APPLES
}

\author{
R.M. BERESFORD ${ }^{1}$, C.H. WEARING ${ }^{2}$, R.R. MARSHALL ${ }^{2}$, \\ P.W. SHAW ${ }^{3}$, M. SPINK ${ }^{4}$ and P.N. WOOD ${ }^{5}$ \\ The Horticulture and Food Research Institute of New Zealand Ltd., \\ ${ }^{1}$ Mt. Albert Research Centre, Private Bag 92 169, Auckland \\ ${ }^{2}$ Clyde Research Centre 160 Earnscleugh Road, RD1 Alexandra \\ ${ }^{3}$ Nelson Research Centre, PO Box 220, Motueka \\ ${ }^{4}$ Canterbury Research Centre, P.O. Box 51 Lincoln, Canterbury \\ ${ }^{5}$ Havelock North Research Orchard, Private Bag 1401 Havelock North
}

\begin{abstract}
Five apple field trials investigated the effects of alternative fungicides on apple black spot (Venturia inaequalis), powdery mildew (Podosphaera leucotricha), European red mite (Panonychus ulmi) and the predatory mite (Typhlodromus pyri). Slaked lime (calcium hydroxide) controlled black spot but not powdery mildew and addition of mineral oil (Sunspray Ultrafine) had little effect. Baking soda (sodium bicarbonate) gave about the same degree of black spot control as slaked lime and also gave slight control of powdery mildew. Addition of mineral oil to baking soda appeared to improve powdery mildew control but not black spot control. A cupric hydroxide plus sulphur mixture gave better black spot control than slaked lime or baking soda and a programme of conventional synthetic fungicides gave better black spot and powdery mildew control than baking soda and oil. Slaked lime reduced predator mite numbers and might therefore disrupt integrated mite control. Neither baking soda nor oil $(125 \mathrm{ml} / 100$ litres water) affected mite numbers.
\end{abstract}

Keywords: apple diseases, soft fungicides, apple scab, calcium hydroxide, sodium bicarbonate, mineral oil

\section{INTRODUCTION}

The use of synthetic fungicides in apple production is under threat for reasons which include pathogen resistance to fungicides, environmental pollution, human health concerns and unacceptability to importing countries of chemical use on fruit crops. While some of the arguments against synthetic fungicide use may not be rational, the threat to exports is real, as is the imperative to find alternatives. In New Zealand several alternative chemicals have recently been tested for efficacy against black spot (Venturia inaequalis) and powdery mildew (Podosphaera leucotricha) (Beresford et al. 1991). Copper and sulphur mixtures were the most fungicidal, but copper caused unacceptable fruit russet. Slaked or hydrated lime (calcium hydroxide, $\mathrm{Ca}(\mathrm{OH})_{2}$ ) has been shown to control apple black spot in Tasmania (Wong et al. 1995) and in New Zealand (Beresford et al. 1995). Baking soda (sodium bicarbonate, $\mathrm{NaHCO}_{3}$ ) has not been tested on apples in New Zealand, but has been reported to control powdery mildews, including rose mildew (Sphaerotheca pannosa var. rosae). Control of black spot (Diplocarpon rosae) on roses has also been reported (Horst and Kawamoto 1992). Mineral spraying oils, which are used in apples for control of scale insects, mites, woolly apple aphid and mealy bugs, have also been shown to be fungicidal (Calpouzos 1966) and their possible effect on apple powdery mildew is of particular interest. 
This paper summarizes five field trials in the New Zealand apple growing regions of Hawke's Bay, Nelson, Canterbury and Otago, which investigated the use of slaked lime and baking soda in combination with mineral oil for black spot and powdery mildew control in apples. Effects on integrated mite control were also investigated in Nelson.

\section{MATERIALS AND METHODS}

Five field trials on HortResearch orchards were randomized block designs with 4-5 replicate plots per treatment. Chemical application was by dilute spraying ( $\mathrm{ca}$. 2000 litres/ha) using hydraulic nozzles. Sprays were applied between September and February, at 7-10 day intervals during the primary infection season (SeptemberNovember) of $V$. inaequalis (Manktelow and Beresford 1995) and at 14-21 day intervals from December to harvest. Sites, cultivars and spray treatments were as follows (chemical amounts given are rates of product per 100 litres water):

\section{Lincoln, Canterbury, 1995-96}

Royal Gala and Fuji; 6 treatments: 1) slaked lime (SL) (1.6 kg) alone; 2)-5) SL (1.6 $\mathrm{kg}$ ) mixed with 60, 120, 250, $500 \mathrm{ml}$ mineral oil (MO, Sunspray Ultrafine, narrow distillation range spray oil); 6) $120 \mathrm{ml} \mathrm{MO}$ alone. There were nine spray applications with harvest of Royal Gala on 29 February and Fuji on 28 April 1996.

\section{Appleby, Nelson, 1995-96}

Royal Gala; 5 treatments: 1) SL (1.6 kg) + MO (125 ml); 2) SL (1.6 kg); 3) baking soda (BS) (1 kg up to 24 November 1995, thereafter $0.5 \mathrm{~kg})+\mathrm{MO}(125 \mathrm{ml})$; 4) BS (1 $\mathrm{kg}$ then $0.5 \mathrm{~kg}) ; 5$ ) unsprayed. There were 16 spray applications with harvest on 20 February 1996. The effects of slaked lime, baking soda and mineral oil on populations of European red mite (Panonychus ulmi) and the predatory mite Typhlodromus pyri were investigated by monitoring mite numbers at two dates. Fifty-leaf samples were collected from treatments 1)-4) on 12 January and treatments 2) and 4) on 7 March 1996. Leaves from the four replicates of each treatment were bulked and mites were removed with a mite brushing machine then counted under a binocular microscope.

\section{Clyde, Otago, 1994-95}

Royal Gala, Braeburn and Fuji; 4 treatments: 1) cupric hydroxide + sulphur $(\mathrm{C}+\mathrm{S})$ (Shell Kocide 101, 32 g + BASF Kumulus DF, 180 g); 2) SL (1.6 kg); 3) BS (1.0 kg); 4) BS $(1.0 \mathrm{~kg})+\mathrm{MO}(125 \mathrm{ml})$. There were 10 applications with harvest of Royal Gala on 13 March, Braeburn on 5 April and Fuji on 18 April 1995. Cupric hydroxide was excluded from Treatment 1 between full bloom and petal fall in an attempt to reduce the amount of fruit russet.

\section{Clyde, Otago, 1995-96}

Royal Gala, Braeburn and Fuji; 3 treatments: 1) C+S (32 g + $180 \mathrm{~g})$; 2) SL (1.6 $\mathrm{kg})$; 3) SL (1.6 kg) + MO (125 ml). There were nine applications with harvest of Royal Gala on 13 March, Braeburn on 28 March and Fuji on 15 April 1996.

\section{Havelock North, Hawke's Bay, $1995-96$}

Royal Gala; 5 treatments: 1) BS (500 g) + MO (500 ml); 2) BS (500 g) + MO (200 $\mathrm{ml})$; 3) BS (500 g) + detergent (Sunlight dish washing liquid, $100 \mathrm{ml}$ ); 4) industrystandard black spot programme, comprising 6 captan, 1 dodine, 5 metiram, 4 demethylation inhibitor (DMI) applications, at recommended rates and spray timing; 5) unsprayed. There were 13 application dates and harvest was on 16 February 1996.

\section{Disease and fruit quality measurements}

Disease assessments followed methods described by Beresford and Manktelow (1995). Black spot incidence on fruit was assessed in all trials on 100-300 fruit per plot at harvest. Black spot and powdery mildew on leaves were assessed as percentage of leaves per shoot affected on ten terminal shoots per tree and 3-5 trees per plot. Fruit russet was measured as the percentage of fruit not suitable for export due to russeting, as determined by New Zealand Apple and Pear Marketing Board standards.

\section{Data presentation}

The data in tables and graphs are untransformed means. For analyses of variance arcsine transformation was applied to data sets where variances of percentages needed to be stabilized. Statistical separation between the means shown in histograms was determined by Duncan's multiple range test. 


\section{Lincoln 1995-96}

\section{RESULTS}

Black spot incidence on leaves on 12 December showed no significant response to the various concentrations of mineral oil mixed with slaked lime (Fig. 1A). Mineral oil alone had significantly $(\mathrm{P}=0.02)$ more black spot than the treatments with slaked lime. Fig. 1A shows means over the two cultivars, Royal Gala and Fuji, which were not significantly different $(\mathrm{P}=0.94)$. At fruit harvest (Fig. 1B) the overall cultivar effect was not significant $(\mathrm{P}=0.41)$, but the interaction between cultivar and treatment was significant $(\mathrm{P}<0.001)$, indicating that the trend for black spot control in Royal Gala to worsen with increasing oil concentration and in Fuji to improve was a real effect. Mineral oil alone gave a higher incidence of black spot than the slaked lime plus mineral oil treatments $(\mathrm{P}<0.001)$ and Royal Gala had significantly more black spot than Fuji $(\mathrm{P}<0.005)$. These results show that slaked lime gave substantial black spot control but that mineral oil did not, either alone or in combination with slaked lime. Mineral oil actually increased black spot in Royal Gala compared to Fuji.

Importantly, there was no significant response of powdery mildew incidence to mineral oil concentration $(\mathrm{P}=0.81)$ (Fig. $1 \mathrm{~A})$. Given that there was no powdery mildew response to mineral oil, and that oil alone had the same level of powdery mildew as the slaked lime treatments, then slaked lime gave no powdery mildew control either. This confirms previous trial results (Beresford et al. 1995). None of the spray treatments had a significant effect on fruit russet.

A. 12 December, leaves

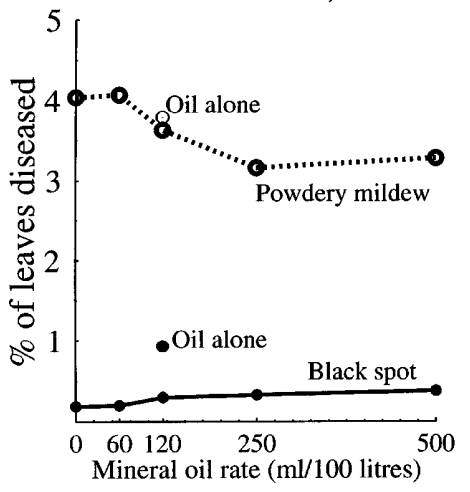

B. Harvest, fruit

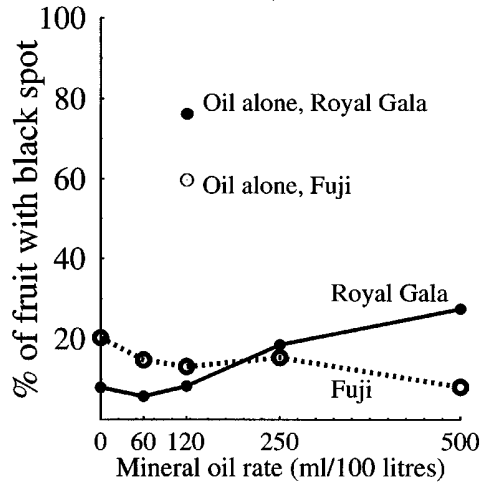

FIGURE 1: Lincoln, 1995-96 Royal Gala and Fuji trial showing responses of, A) black spot and powdery mildew on leaves on 12 December and B) black spot on fruit at harvest, to different application rates of mineral oil mixed with $1.6 \mathrm{~kg}$ slaked lime/100 litres water and to oil alone at $120 \mathrm{ml} / 100$ litres water.

\section{Appleby 1995-96}

Slaked lime and baking soda both decreased black spot to the same degree on leaves and fruit compared to unsprayed, both in December and at harvest. Fruit harvest data are shown in Table 1. There was no significant oil effect, confirming the results from Lincoln, that mineral oil did not improve black spot control.

Baking soda caused an increase in fruit russet resulting in a significant decrease in exportable fruit (Table 2). Slaked lime resulted in as little russet as the unsprayed treatment. Baking soda was clearly phytotoxic and the initial application rate of $1 \mathrm{~kg} /$ 100 litres was reduced to $0.5 \mathrm{~kg}$ in December when leaf burning was noticed in baking soda treatments. Mineral oil at the $125 \mathrm{ml} / 100$ litres rate used caused no fruit russet. 
TABLE 1: Percentage of fruit with black spot at harvest for slaked lime and baking soda treatments, with and without mineral oil, Appleby, $1995-96$.

\begin{tabular}{|c|c|c|c|}
\hline $\begin{array}{l}\text { Fungicide } \mathrm{x} \text { oil } \\
\text { interaction }(\mathrm{NS})^{1}\end{array}$ & With oil & Without oil & $\begin{array}{l}\text { Fungicide means } \\
(\mathrm{NS})^{1}\end{array}$ \\
\hline Slaked lime & 51.2 & 63.2 & 57.2 \\
\hline Baking soda & 64.8 & 57.5 & 61.1 \\
\hline Oil means $(\mathrm{NS})^{1}$ & 58.0 & 60.4 & \\
\hline
\end{tabular}

${ }^{1}$ Not significant, $\mathrm{P}>0.05$

Unsprayed $=96.8$, significantly different from treatments in a separate analysis, $\mathrm{P}=0.023$.

TABLE 2: Percentage of fruit with russet levels acceptable for export, for slaked lime and baking soda treatments, with and without mineral oil, Appleby, 1995-96.

\begin{tabular}{lccc}
\hline $\begin{array}{l}\text { Fungicide } \mathrm{x} \text { oil } \\
\text { interaction (NS) }\end{array}$ & With oil & Without oil & Fungicide means *** \\
\cline { 1 - 1 } Slaked lime & & & \\
Baking soda & 99.8 & 98.3 & 99.0 \\
Oil means (NS) & 81.8 & 86.8 & 84.3 \\
\hline
\end{tabular}

${ }^{1}$ Not significant, $\mathrm{P}>0.05$

*** Significantly different, $\mathrm{P}<0.001$

Unsprayed $=100.0$, significantly different from baking soda, but not slaked lime, in a separate analysis, $\mathrm{P}<0.001$.

Powdery mildew was assessed on leaves on 18 December. There were no significant differences among the treatments $(\mathrm{P}=0.14)$, and the ranking of means for percentage of leaves diseased was BS+MO $(13 \%)<\mathrm{BS}(18 \%)<\mathrm{SL}(20 \%)<\mathrm{SL}+\mathrm{MO}$ $(21 \%)<$ unsprayed $(26 \%)$. Thus the two baking soda treatments tended to have less powdery mildew than the other treatments.

Predatory mite (T. pyri) numbers, both active stages and eggs, were lower in treatments with slaked lime than with baking soda (Table 3). Results from the 12 January sample suggested that oil had no effect on $T$. pyri numbers. There appeared to be fewer P. ulmi eggs at the 7 March assessment in the slaked lime treatment and it is possible that slaked lime reduced numbers of both predator and pest mites. Although it appears that slaked lime had an adverse effect on $T$. pyri, further studies are required before it can be concluded that slaked lime is likely to disrupt integrated mite control.

TABLE 3: Numbers of European red mites (P. ulmi) and predatory mites $T$. pyri per fifty leaves for slaked lime (SL), baking soda (BS) and mineral oil (MO) treatments on two dates at Appleby in 1995-96.

\begin{tabular}{llcccc}
\hline $\begin{array}{l}\text { Sample } \\
\text { date }\end{array}$ & Treatment & P. ulmi & $\begin{array}{c}\text { P. ulmi } \\
\text { eggs }\end{array}$ & T. pyri & $\begin{array}{c}\text { T. pyri } \\
\text { eggs }\end{array}$ \\
\hline $12 / 1 / 96$ & 1. SL+MO & 3 & 21 & 4 & 0 \\
& 2. SL-MO & 4 & 8 & 1 & 0 \\
& 3. BS+MO & 4 & 16 & 20 & 1 \\
$7 / 3 / 96$ & 4. BS-MO & 1 & 37 & 25 & 9 \\
& 2. SL-MO & 34 & 28 & 14 & 0 \\
& 4. BS-MO & 32 & 112 & 68 & 4 \\
\hline
\end{tabular}




\section{Clyde 1994-95, 1995-96}

Trials at Clyde used cupric hydroxide plus sulphur as a standard for comparison. Application rates were derived from earlier trials (Beresford et al. 1995) to give reasonable disease control while minimizing fruit russeting due to the presence of copper. In 1994-95, black spot responses to spray treatments were similar for all cultivars (Fig. 2A). Treatment means analysed over all cultivars ranked as follows: $\mathrm{C}+\mathrm{S}(0.6 \%)<\mathrm{BS}+\mathrm{MO}(4.5 \%)<\mathrm{SL}(5.2 \%)<\mathrm{BS}(12.3 \%) ; \mathrm{LSD}_{0.05}=4.4 \%$. Thus, baking soda alone was significantly worse than the other treatments and adding oil to baking soda improved black spot control compared to baking soda alone. There were no significant spray treatment effects on russet, and in this trial baking soda at $1 \mathrm{~kg} / 100$ litres did not cause the russeting and the leaf burning found at Appleby.

Powdery mildew incidence, on 5 December 1994, showed no significant $(\mathrm{P}>0.05)$ treatment differences. Mean percentages of leaves diseased over the three cultivars were: $\mathrm{BS}+\mathrm{MO}(13 \%)<\mathrm{C}+\mathrm{S}(16 \%)<\mathrm{BS}(17 \%)<\mathrm{SL}(19 \%)$. On 23 January 1995 there was a significant treatment effect, with the following ranking: $\mathrm{BS}+\mathrm{MO}(13 \%)<\mathrm{BS}$ $(17 \%)=\mathrm{C}+\mathrm{S}(17 \%)<\mathrm{SL}(22 \%) ; \mathrm{LSD}_{0.05}=6 \%$. Thus, baking soda plus mineral oil significantly reduced powdery mildew compared to slaked lime. As at Appleby, powdery mildew control with baking soda appeared to be improved with the addition of mineral oil. This contrasts with slaked lime at Lincoln, where addition of mineral oil did not improve powdery mildew control.

In 1995-96, C+S consistently gave the best black spot control (Fig. 2B). SL gave relatively poor control in all cultivars. The trend detected at Lincoln, whereby mixing mineral oil with slaked lime improved black spot control in Fuji but not in Royal Gala, was also found here. Powdery mildew data were not available for the 1995-96 trial at the time of writing.
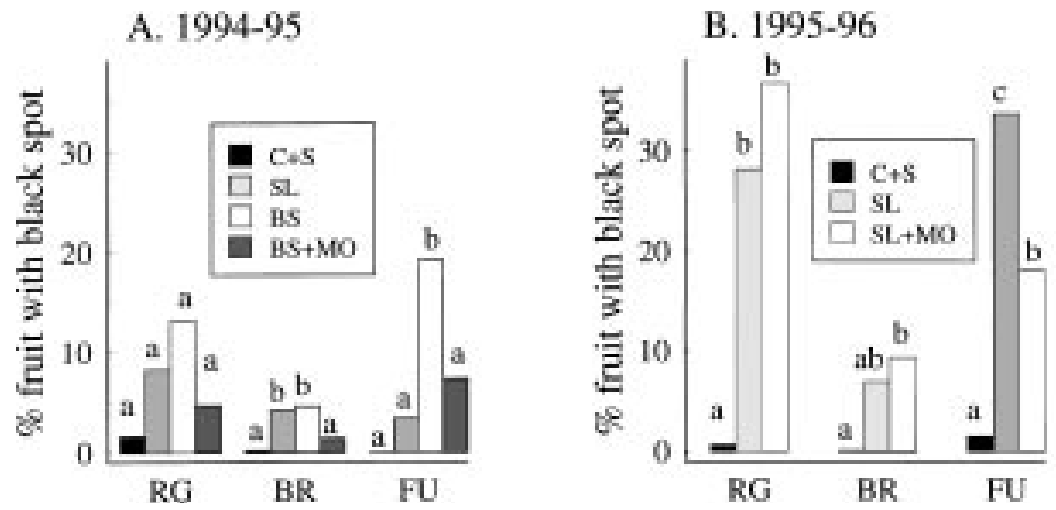

FIGURE 2: Black spot incidence in spray treatments at Clyde; A) 1994-95 and B) 1995-96. $\mathrm{C}=$ cupric hydroxide, $\mathrm{S}=$ sulphur, $\mathrm{SL}=$ slaked lime, $\mathrm{BS}=$ baking soda, $\mathrm{MO}=$ mineral oil, $\mathrm{RG}=$ Royal Gala, $\mathrm{BR}=$ Braeburn, FU= Fuji. Bars within a cultivar with the same letter are not significantly different $(\mathbf{P}>\mathbf{0 . 0 5})$.

\section{Havelock North 1995-96}

Unsprayed plots had significantly more black spot and powdery mildew than the baking soda treatments and the industry-standard spray programme had significantly less (Fig. 3). For black spot, BS+500 ml MO was not significantly different from $\mathrm{BS}+200 \mathrm{ml} \mathrm{MO}$, suggesting that the addition of mineral oil to baking soda did not improve black spot control. This reflects the Appleby result and contradicts the Clyde 


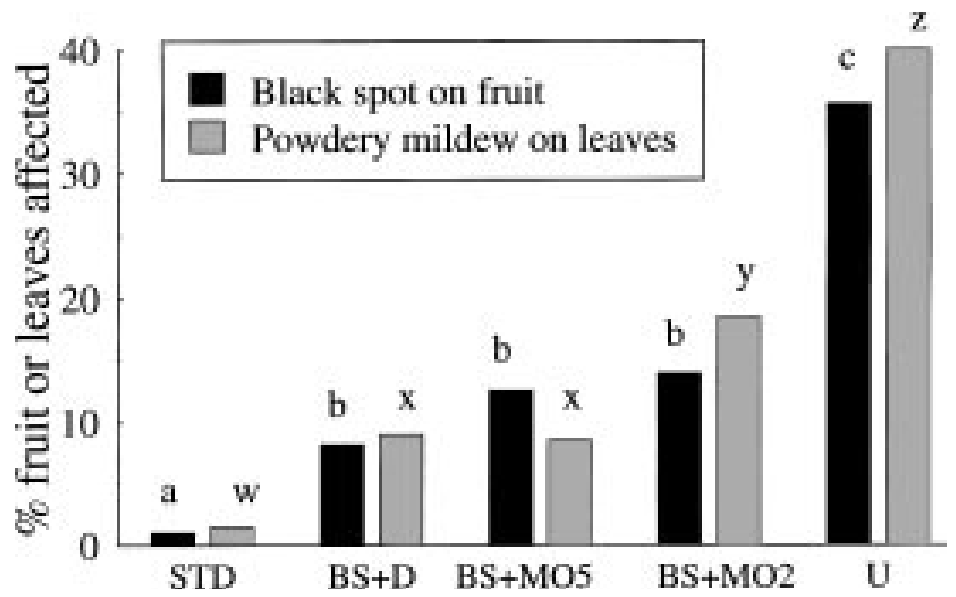

FIGURE 3: Black spot on fruit on 16 February 1996 (harvest) and powdery mildew on leaves on 12 December at Havelock North. Treatments: $\mathrm{STD}=$ industry standard, $\mathrm{BS}+\mathrm{D}=$ baking soda + detergent, BS+MO5= baking soda $+500 \mathrm{ml}$ mineral oil, BS+MO2= baking soda $+200 \mathrm{ml}$ mineral oil, $\mathrm{U}=$ unsprayed control. For each disease, bars with the same letter are not significantly different $(P>0.05)$.

1994-95 result, where control was significantly better when mineral oil was added to baking soda, compared to baking soda alone. BS+detergent also gave a similar level of black spot control to the BS+MO treatments.

For powdery mildew, control was significantly better with the higher rate of mineral oil mixed with baking soda than with the lower rate, confirming the Appleby and Clyde 1994-95 results that addition of mineral oil to baking soda enhances powdery mildew control. Baking soda plus detergent was as effective for powdery mildew control as baking soda plus the higher rate of mineral oil.

\section{DISCUSSION}

These trials confirm earlier results (Beresfordet al. 1995) that slaked lime controls black spot on New Zealand apple cultivars without phytotoxicity and that it does not control powdery mildew. The mode of action of slaked lime against $V$. inaequalis is through its alkalinity. It maintains plant surfaces at $\mathrm{pH}$ 8.5-9.0 which inhibits spore germination and infection (Wong et al. 1993). Water glass (sodium silicate), washing soda (sodium carbonate) and borax (sodium tetraborate) also produce the same effect. Slaked lime is preferred because of its low mammalian toxicity and because it breaks down to calcium carbonate in the air. There is an indication from our Appleby trial, however, that slaked lime may inhibit mite predators, which could interfere with integrated mite control. Mites may be affected by the high $\mathrm{pH}$, and as integrated mite control is an important aspect of apple crop protection, further investigation of the effects of alkaline chemicals on mite predators is required before slaked lime is recommended for apple black spot control.

Baking soda was generally as effective as slaked lime for $V$. inaequalis control. It caused russeting and leaf burning at Appleby but phytotoxicity was not observed at Clyde or Havelock North. Baking soda appeared to control powdery mildew, although the effects in these trials were often barely significant. Baking soda has been widely reported as controlling powdery mildews both overseas (e.g. Horst and Kawamoto 1992; Ziv and Zitter 1992) and in New Zealand (Long et al. 1995; Wood et al. 1995). 
Although like slaked lime, baking soda is alkaline ( $\mathrm{pH}$ in solution 8.3-8.5), it is the bicarbonate ion that is fungicidal (Marloth 1931). Other bicarbonate and carbonate salts are also toxic to various fungi at concentrations from $0.5-1.0 \mathrm{~kg} / 100$ litres, and some are reported to be phytotoxic (Ziv and Zitter 1992). Although no reports were found of $V$. inaequalis control with baking soda, Horst and Kawamoto (1992) showed that baking soda at $0.063 \mathrm{M}(0.529 \mathrm{~kg} / 100$ litres $)$ reduced the severity of rose black spot (Diplocarpon rosae).

Mineral oil had only a small effect on black spot when mixed with slaked lime and it was cultivar dependent, such that oil increased black spot on Royal Gala compared to Fuji. Oil by itself did not appear to be fungicidal against black spot or powdery mildew. Powdery mildew control with baking soda was improved by the addition of mineral oil, whereas, addition of mineral oil to slaked lime gave no improvement. Addition of mineral oil to baking soda has also given significant improvements in powdery mildew control in apple cultivars resistant to black spot at Clyde (Wearing and Marshall unpublished data).

Mineral oils have been reported to be fungicidal against various powdery mildews (Northover and Schneider 1993), but not against V. inaequalis (Northover and Schneider 1996). The mode of fungicidal action probably varies between different oils and may involve protective, sporulation suppressive and curative effects (Calpouzos 1966). Surfactants and film forming polymers are also reported to control powdery mildews (Hislop et al. 1978; Elad et al. 1989; Horst and Kawamoto 1992). Mineral oil rates chosen for these trials were deliberately low to avoid russeting of fruit. Recommended rates for invertebrate pest control are 2 litres/ 100 litres up to tight cluster stage and 1 litre for summer application (Fussell and Walton 1995). It is possible that rates were too low give disease control, although the rate responses from Lincoln (Fig. 1) suggest that large improvements in disease control at increased rates may be unlikely. Further investigations of fungicidal activity and phytotoxicity of higher application rates of mineral oils are needed on New Zealand apple cultivars.

While the alternative fungicides tested in these trials reduced disease levels, their efficacy is clearly intermediate between no treatment and treatment with conventional synthetic fungicides. Problems of low efficacy, limited activity spectrum and phytotoxicity preclude alternative fungicides from being used as simple replacements for conventional fungicides. The search for alternative chemicals with better than intermediate efficacy must continue and the new challenge is to incorporate promising alternatives into fungicide programmes which will gain general acceptance by apple growers.

\section{ACKNOWLEDGEMENTS}

The authors thank the Foundation for Research, Science and Technology for funding this research.

\section{REFERENCES}

Beresford, R.M. and Manktelow, D.W.L., 1995. Methods for disease assessment in apples, including growth stages, leaf emergence, black spot and powdery mildew. Proc. 48th N.Z. Plant Prot. Conf.: 89-94.

Beresford, R.M., Elmer, P.A.G., Spink, M., Alexander, R.T. and Daly, M.J., 1991. Fungicides for control of black spot and powdery mildew in organic apple production systems. Proc. 44th N.Z. Weed and Pest Control Conf.: 86-90.

Beresford, R.M., Wearing, C.H., Walker, J.T.S., Spink, M., Marshall, R.R. and White, V., 1995. Copper and slaked lime for the control of black spot and powdery mildew in apples. Proc. 48th N.Z. Plant Prot. Conf.: 83-88.

Calpouzos, L., 1966. Action of oil in the control of plant disease. Ann. Rev. Phytopath. 4: 369-390.

Elad, Y., Ziv, O., Ayish, N. and Katan, J., 1989. The effect of film-forming polymers on powdery mildew of cucumber. Phytoparasitica 17: 279-288.

Fussell, A. and Walton, T., 1995. New Zealand Agrichemical Manual, master edition. Wham Chemsafe Ltd: 24-26. 
Hislop, E.C., Clifford, D.R., Holgate M.E. and Gendle, P., 1978. Eradication of apple powdery mildew (Podosphaera leucotricha) with dormant-season sprays of surface-active agents. Pesticide Sci. 9: 12-21.

Horst, R.K. and Kawamoto, S.O., 1992. Effect of sodium bicarbonate and oils on control of powdery mildew and black spot of roses. Plant Dis. 76: 247-251.

Long, P.G., Weeds, P., Wood, P., Tate, G. and Bayler, C., 1995. Baking soda and additives for control of powdery mildews. Proc. 10th Austral. Plant Path. Soc. Conf., Lincoln, New Zealand: p.54 (abstract).

Manktelow, D.W.L. and Beresford, R.M., 1995. Evaluation of an ascospore monitoring method forVenturia inaequalis to improve apple black spot fungicide management. Proc. 48th N.Z. Plant Prot. Conf.: 78-82.

Marloth, R.H., 1931. The influence of hydrogen-ion concentration and of sodium bicarbonate and related substances on Penicillium italicum and P. digitatum. Phytopath. 21: 169-198.

Northover, J. and Schneider, K.E., 1993. Activity of plant oils on diseases caused by Podosphaera leucotricha, Venturia inaequalis and Albugo occidentalis. Plant Dis. 77: 152-157.

Northover, J. and Schneider, K.E., 1996. Physical modes of action of petroleum and plant oils on powdery and downy mildews of grapevines.Plant Dis. 80: (in press).

Wong, J.A.L., O’Loughlin, J., Schupp, J.K. and Williams, W., 1993. High pH on leaf and fruit surfaces as a control strategy for apple scab. Proc. 9th Austral. Plant Path. Soc. Conf., Hobart: p.58 (abstract).

Wong, J.A.L., Archer, C., Schupp, P., Williams, W.G. and O’Loughlin, J., 1995. Commercial adoption of hydrated lime for apple scab control in Australia. Proc. 10th Austral. Plant Path. Soc. Conf., Lincoln, New Zealand: p.55 (abstract).

Wood, P.N., Tate, G., Long, P. and Bayler, C., 1995. Control of grape powdery mildew (Uncinula necator) with foliar sprays of soft fungicides. Proc. 10th Austral. Plant Path. Soc. Conf., Lincoln, New Zealand: p.54 (abstract).

Ziv, O. and Zitter, T.A., 1992. Effects of bicarbonates and film-forming polymers on cucurbit foliar diseases. Plant Dis. 76: 513-517. 